\title{
Реиндустриализация без своих РЗМ?
}

В.А. КРЮКОВ, член-корреспондент РАН, заведующий Центром ресурсной экономики ИЭОПП СО РАН, Новосибирск, научный руководитель магистерской программы НИУ-ВШЭ, Москва.

С.А. ЗУБКОВА, магистрант программы «Управление и регулирование энергетическими и сырьевыми рынками», НИУ-ВШЭ, Москва

В статье рассматриваются проблемы и направления освоения и применения редкоземельных металлов (РЗМ) в России и в ряде стран мира. Показано, что в разных странах имеет место значительное своеобразие при формировании технологических цепочек их использования. Рассмотрен опыт Китая в становлении и развитии индустрии РЗМ. Отличительная особенность Китая состоит, по мнению авторов, в пошаговом подходе к формированию современной индустрии. Россия основной акцент делает на поиск и разведку источников РЗМ, а также на проведение научно-исследовательских работ по определению направлений и сфер их эффективного применения. Вопросам формирования эффективного спроса внутри страны при этом уделяется значительно меньше внимания, чем необходимо.

Ключевые слова: редкоземельные металлы, технологические цепочки, формирование спроса, достижение баланса между спросом и предложением

\section{О наболевшем}

«ЭКО» не раз (см. посвященные этой теме подборки материалов в № 11 за 2012 г. и № 2 за 2014 г.) освещал с разных сторон [1] проблемы освоения и использования новых уникальных источников сырья, содержащих редкоземельные металлы ${ }^{1}$.

\footnotetext{
${ }^{1}$ Международный союз теоретической и прикладной химии (IUPAC) относит кредкоземельным металлам (РЗМ), или редкоземельным элементам (РЗЭ) (Rare Earth Metals - REM, Rare Earth Elements - REE) совокупность 17 элементов периодической системы. Это 15 лантаноидов, имеющих порядковые номера от 57 до 71 (лантан, церий, празеодим, неодим, прометий, самарий, европий, гадолиний, тербий, диспрозий, гольмий, эрбий, туллий, иттербий, лютеций) и, кроме того, скандий и иттрий (порядковые номера, соответственно, 21 и 39), которые схожи по химическим свойствам с лантаноидами и располагаются в одних месторождениях и рудахс ними. РЗМ разделяют на две группы: легкие и тяжелые. К легким относят лантан, церий, празеодим, неодим, прометий, самарий, европий, гадолиний (порядковые номера 57-64), к тяжелым - тербий, диспрозий, гольмий, эрбий, туллий, иттербий, лютеций (порядковые номера 65-71), а также, по схожести химических свойств, иттрий (порядковый номер 39). Скандий по этой классификации не принадлежит ни к одной из групп. Легкие РЗМ более распространены в природе и легче извлекаются, тяжелые менее доступны и более сложны для добычи [1].
} 
Главный вывод этих публикаций заключается в том, что наличие в России источников уникальных полезных ископаемых дает стране шанс сформировать мощный высокотехнологичный сегмент на основе «естественных» условий и предпосылок. Используя знания, умения и навыки, накопленные представителями самых разных профессий и областей знания (от геологии до инженерного дела) в сфере создания высокотехнологичной продукции, наша страна имеет возможность создать совокупность уникальных направлений развития отечественной экономики на основе использования редкоземельных элементов и металлов (далее - РЗМ). В этом случае обеспечивается весьма редкое сочетание современных сырьевой экономики (освоение источников минерально-сырьевых ресурсов) с экономикой новых материалов и высокотехнологичных изделий [2]. Тем самым уникальное сырье и уникальные знания о его возможностях могут позволить преодолеть ставшую притчей во языцех «сырьевую зависимость».

Роль редкоземельных металлов в современной экономике объясняется их особыми физическими и химическими свойствами, делающими их незаменимыми для развития высокотехнологичных, наукоемких отраслей. РЗМ называют «двигателями мировой экономики» [3. С.63]. Не случайно в нормативных документах данные элементы относят либо к «стратегическим», либо к «критическим» [4].

Высокотехнологичные производства играют ключевую роль в обеспечении конкурентоспособности экономики, в то же время их развитие во многом зависит от надежного доступа к качественным (по потребительским свойствам и ценовым характеристикам) сырьевым ресурсам. В 2010-2012 гг. развитые страны, импортирующие большие объемы РЗМ, столкнулись с угрозой недопоставок сырья. Сокращение предложения на рынке и последовавшие закупки редкоземельных металлов в запасы вызвали резкий скачок цен. Заметим, что в настоящее время производство РЗМ концентрируется преимущественно в развивающихся странах, а конечный продукт потребляют развитые - США, Япония, ЕС, Южная Корея и др. В мире спрос на РЗМ и другие «новые полезные ископаемые» определяется быстрым развитием не только информационных технологий, но и альтернативной энергетики. О масштабах этих процессов дает представление 
рост потребления лития - компания Goldman Sachs прогнозирует, что рост мирового рынка электромобилей только на $1 \%$ в год связан с увеличением спроса на литий в объеме 70 тыс. т ежегодно, что эквивалентно трети мирового потребления данного металла в 2015 г.

Важнейшие особенности производства редкоземельных металлов таковы:

- в природе они находятся в рассеянном состоянии; минералы самых богатых месторождений содержат до 5\% редких земель;

- процесс отделения РЗМ друг от друга и выделения индивидуальных металлов сложен и дорогостоящ;

- в рудах наблюдается высокая диспропорция содержания легких и тяжелых РЗМ;

- существуют высокие экологические риски, связанные с наличием радиоактивных элементов в месторождениях.

Значительная часть стран, на территории которых разрабатываются месторождения редких земель, не имеет мощностей для их обогащения и потому продает дешевые полупродукты, и наоборот. Эта ситуация характерна, в частности, для стран постсоветского пространства, где единая технологическая цепь, объединявшая Россию, Казахстан, Киргизию, Эстонию, была разрушена.

Важнейшая особенность месторождений РЗМ - большой разброс их процентного содержания в рудах и различный состав металлов. Поэтому обычный анализ рынка через изучение спроса и предложения в целом по всем РЗМ малоинформативен. Поскольку все 17 элементов содержатся в разном соотношении в одних и тех же рудах, возникает диспропорция добычи и предложения: как правило, легких РЗМ добывается больше, вследствие чего цена на них ниже, чем на тяжелые. Часто наблюдается дефицит одних РЗМ при одновременном профиците других.

В настоящее время идет сокращение доли Китая в мировом производстве РЗМ: по данным Геологической службы США, в 2015 г. она составляла чуть менее $85 \%$. Одновременно растут доли Австралии (8\% в 2015 г.) и США (около 4\%). Доля России почти неизменна (2\% в 2015 г., хотя в 1990 г. приближалась к 10\%). При этом 70\% РЗМ потребляет «Ростех», 20-25\% - «Росатом», остальные 5-10\% используют в металлургии, нефтехимии (ОАО «Газпром нефтехим Салават», ОАО «Газпром-ОНПЗ») и других сферах [5]. 
Китай в весьма короткие сроки сконцентрировал на своей территории более 97\% мощностей по добыче и переработке РЗМ (располагая при этом примерно 30\% мировой ресурсной базы). Более того, Китай простимулировал перенос высокотехнологичных производств с применением РЗМ на свою территорию и создал многие наукоемкие отрасли, которые вносят весомый вклад в экономику страны за счет высокой добавленной стоимости.

Поэтому, как правило, все исследования, оценки и вытекающие из них практические предложения исходят из постулата важности РЗМ в создании современной высокотехнологичной промышленности и анализа политики Китая (в основном в контексте стремления к монополизации мирового производства и торговли сначала РЗМ, а затем и основными «крупнотоннажными» продуктами с их применением). Предлагаемые шаги и меры, как правило, предполагают усиление роли государства в связи со «стратегическим» и «критическим» характером РЗМ для нужд национальной обороны (вплоть до прямого участия в данной деятельности путем создания госкорпораций).

Такой подход оказался явно недостаточным для преодоления отставания в развитии добычи и использования РЗМ в России, поэтому в последнее время все чаще приводятся аргументы в пользу того, что наряду с производством (добыча, обогащение, выпуск новых изделий) необходимо развивать спрос на РЗМ и изделия на их основе внутри страны.

Все это можно признать «движением в правильном направлении», однако современная динамика производства и потребления РЗМ определяется не только (и не столько) государственно-политическими решениями и приоритетами (хотя их нельзя сбрасывать со счетов), сколько причинами «традиционного экономического свойства» - низкими издержками, а также соотношением спроса и предложения. При всей важности «стратегических» и «критических» соображений в основе мер по развитию индустрии РЗМ должны лежать экономическая отдача и экономические результаты.

Это выдвигает на передний план непростую проблему соотношения государства и рынка, экономики и политики. Каждая страна пытается найти определенный баланс соотношений этих «двух действующих начал». России данный опыт может быть полезен тем, что вне экономики, т. е. достижения приемлемых эко- 
номических результатов, никакие меры государственного участия в решении данной проблемы не смогут обеспечить долгосрочный и устойчивый тренд развития производства и использования отечественных РЗМ и материалов на их основе. К сожалению, экономика в этой сфере «не слышна и почти не видна».

В этом и заключается основная идея, которую авторы хотели бы донести до читателей журнала.

\section{Россия - в поисках своего пути}

Наша страна имеет колоссальный опыт разработки и реализации научно-технических программ и экономических планов, который, с одной стороны, облегчает решение отдельных задач, a c другой - создает препятствия и ограничения на пути движения вперед. Именно влиянием нашего исторического опыта можно объяснить увлечение такими стандартными подходами к решению научно-технических проблем, как разработка и утверждение федеральных целевых программ (или иных программных документов национального уровня), финансируемых и координируемых на федеральном уровне, а также создание государственных корпораций или компаний, которым поручается достижение общенациональных целей (о других приоритетах речи просто не идет).

Именно по такому пути шло развитие РЗМ-индустрии. Прежде всего, определен стратегический статус РЗМ: в соответствии с распоряжением Правительства РФ от 16.01.1996 г. № 50-p «Об основных видах стратегического минерального сырья» редкоземельные металлы иттриевой группы и скандий отнесены к основным видам стратегического минерального сырья.

В 2014 г. принято Постановление Правительства РФ № 328 от 15.04.2014 г. «Об утверждении государственной программы Российской Федерации “Развитие промышленности и повышение ее конкурентоспособности”» [6], в которой отдельно выделена подпрограмма № 15 «Развитие промышленности редких и редкоземельных металлов», цель которой - «создание в Российской Федерации конкурентоспособной редкоземельной промышленности полного технологического цикла для удовлетворения потребностей отечественного оборонно-промышленного комплекса, гражданских отраслей промышленности и выхода на зарубежные рынки» [7]. Подпрограмма включает мероприятия по разработке 
минерально-сырьевой базы РЗМ, адаптации и развитию технологий их использования. В числе основных задач названы:

- разработка, освоение и адаптация ключевых технологий производства редких и редкоземельных металлов полного цикла, в том числе разделения и производства чистых индивидуальных оксидов, чистых металлов и сплавов, а также конечной продукции, содержащей редкие и редкоземельные металлы;

- создание промышленных производств полного технологического цикла (от добычи сырья до конечной продукции, содержащей редкие и редкоземельные металлы), при полном обеспечении потребностей создаваемых конечных производств по всей номенклатуре редких и редкоземельных металлов;

- создание условий для ввода в эксплуатацию и комплексного освоения месторождений редких и редкоземельных металлов, а также техногенных объектов с целью сырьевого обеспечения промышленных производств полного цикла;

- переоценка запасов, учитываемых государственным балансом, и подготовка новых запасов, в том числе в техногенных объектах, с целью обеспечения создаваемых промышленных производств сырьем редких и редкоземельных металлов на долгосрочный период;

- решение кадровых проблем отрасли.

Целевыми индикаторами подпрограммы являются технологии, прошедшие опытную отработку, готовые к коммерциализации и переданные в производство, а также патенты и ноу-хау. В соответствии с логикой формирования подобных документов «от предложения» на период до 2020 г. были рассмотрены и сценарии развития спроса на РЗМ: инерционный, базовый (предусматривающий обеспечение потребностей крупнейших национальных производителей) и оптимистический (ускоренное инновационное развитие с выходом на мировой рынок). В качестве основного выбран базовый сценарий, в соответствии с которым доля России в мировом потреблении РЗМ возрастет на 5-6\%. Структура потребления по сферам применения следующая: производство магнитов, катализаторов для нефтехимии, инновационные проекты.

Результатом сценарного (в каком-то смысле «макроподхода») к формированию документа стало то, что в указанной подпрограмме даже не определен перечень редкоземельных металлов (как и в других нормативных актах - Налоговом кодексе РФ, Ф3 «О недрах» и др.). В отечественной научной и нормативной 
литературе редкоземельные металлы обычно рассматриваются как часть более широкой группы редких металлов [8].

В июне 2016 г. во Всероссийском научно-исследовательском институте авиационных материалов (ВИАМ) состоялось заседание, в ходе которого «... были рассмотрены вопросы реализации научно-исследовательских и опытно-конструкторских работ, a также инвестиционных проектов, выполняемых в рамках подпрограммы "Развитие промышленности редких и редкоземельных металлов"» [9].

В декабре 2015 г. на Коллегии Счетной палаты Российской Федерации был рассмотрен вопрос «О результатах контрольного мероприятия "Проверка расходования средств федерального бюджета и эффективности управления государственным фондом недр редких и редкоземельных металлов в 2011-2014 годах и истекшем периоде 2015 г.”» [10]. Счетная палата отметила, что «в государственном балансе запасов полезных ископаемых Российской Федерации учитывается 16 месторождений, содержащих запасы редкоземельных металлов, и один техногенный объект - Центральная-Нижняя россыпь бассейна реки Урасалах в Республике Саха (Якутия). При этом ряд месторождений находится в неосвоенных районах со сложными климатическими условиями, где отсутствует инфраструктура. Все указанные месторождения являются комплексными и содержат редкоземельные металлы в качестве одного из основных или попутных компонентов. В Российской Федерации добыча и запасы редкоземельных металлов сосредоточены практически в двух субъектах: в Мурманской области - 72,6\% запасов и вся добыча (100\%), Республике Саха (Якутия) - 25,7\% запасов» [10]. В рамках программы, например, в 2015 г. проводились исследования месторождений РЗМ Чуктуконского рудного поля (Красноярский край), на рудопроявлении Отбойное (Иркутская область), в пределах Куларского рудно-россыпного района (Республика Саха (Якутия)), на Северном и Южном участках Томторского рудного поля (Республика Саха (Якутия))» [11].

За то время, когда велись разработка подпрограммы, согласование планов работ, разделение «сфер влияния» (в частности, между «Росатомом» и «Ростехом»), небольшие объемы потребления редкоземельных металлов и элементов, сложившиеся в России, не только не выросли, но и даже несколько снизились: 
«Уровень потребления редкоземельных металлов в России после 1991 г. не превышал 3,0 тыс. т в год (в пересчете на оксиды), хотя на протяжении 70-х и до середины 80 -х годов составлял около 6,0 тыс т в год, в 90-х годах - 8,0 тыс. т)» [10].

В целом, как справедливо отмечается в работе [12], основной акцент и в подпрограмме, и в реализуемых практических шагах был сделан на предложении РЗМ - поиске и разведке источников полезных ископаемых, а также на научно-исследовательских работах, в то время как любая экономическая задача базируется на двух составляющих - формировании предложения и спроса на создаваемую продукцию.

Поэтому ситуация в стране в рассматриваемой области крайне противоречивая. Как отмечается в материалах Счетной палаты, «при высокой обеспеченности Российской Федерации запасами редких и редкоземельных металлов (по ряду металлов - более чем 100 лет, а по рению - более чем 40 лет) потребность экономики... обеспечивается за счет импорта, доля которого по отдельным металлам составляет более 90\%» [10]. При этом «выручка Соликамского магниевого завода (СМЗ, Пермский край) в 2015 г. достигла 6,3 млрд руб. против 5,1 млрд руб. годом ранее. Чистая прибыль составила в прошлом году 474,5 млн руб. против 40 млн руб. в 2014 г. СМЗ поставляет на экспорт почти $100 \%$ производимой редкоземельной продукции и соединений тантала и около $60 \%$ выпускаемого ниобия, а также является основным поставщиком магния и сплавов для российской промышленности» [13].

Причина невостребованности РЗМ внутри страны весьма банальна - отсутствие должного развития высокотехнологичных отраслей и производств в России. В результате при небольших масштабах выпуска редких металлов от 65 до 98\% произведенного продукта экспортируется [12].

Отмеченный нами «рассеянный» характер нахождения в природе редких металлов и редких элементов (они распространены в значительных объемах при чрезвычайно малых концентрациях) предопределил и возможные формы организации производства:

- на крупных комплексных горнорудных производствах РЗМ извлекаются как попутные компоненты при добыче других полезных ископаемых (например, фосфоритов); 
- в составе самостоятельных производств РЗМ производятся в качестве целевых продуктов (при освоении уникальных месторождений, число которых крайне мало (см. [2]), либо мелких и рассредоточенных объектов).

Соответственно, меняются подход и стратегия получения и дальнейшего продвижения сырья, содержащего ценные полезные ископаемые. В первом случае - формирование кооперационных связей и взаимодействий компании-лидера (добывающей целевые полезные ископаемые) с компаниями-партнерами по «утилизации» и комплексному извлечению всех полезных ископаемых, которые содержатся в недрах осваиваемого участка недр. Во втором - налаживание таких связей не столько на стадии добычи и первичного обогащения РЗМ, сколько на этапах продвижения и их последующего использования в высокотехнологичных отраслях. В разных странах - в зависимости от того, как и в каких условиях сформированы цепочки освоения РЗМ, применяются различные подходы к балансировке их производства (добычи) и последующего использования.

Приходится с сожалением констатировать, что в России прежняя модель связи утрачена, новая - пока не найдена. Система государственного регулирования и управления ресурсами РЗМ не нацелена на их использование в национальной экономике. И это проявляется с первых шагов: в балансе учитываются те участки недр, освоение которых неэффективно при существующих системах налогообложения и транспортировки, имеющихся производственных мощностях и, что принципиально важно, доминирующих подходах к организации производства в сфере глубокой переработки. И это только вводит в заблуждение относительно реального ресурсного потенциала тех, кто определяет направления развития РЗМ-индустрии в нашей стране (в этих целях целесообразно учитывать, прежде всего, уникальные объекты, такие, как Томторское месторождение, например).

\section{В разных странах экономика живет по одним законам}

Формирование цепочек от добычи РЗМ до создания высокотехнологичной продукции на их основе и схем взаимодействия внутри этих цепочек базируется на национальных традициях, доступности источников сырья, приоритетах развития 
национальной экономики и промышленности. Ключевым при этом был и остается вопрос создания стимулов и заинтересованности бизнес-сообщества в формировании и поддержании данных цепочек. При этом заинтересованность крупных компаний может проявляться не столько в производственной деятельности в данной области, сколько в сфере содействия и поддержания кооперационных связей и отношений со специализированными наукоемкими перерабатывающими компаниями.

Страна-лидер - Китай. Для Китая, как мы неоднократно отмечали, характерны значительный прагматизм и высокая степень децентрализации управления экономическими процессами. В сфере создания и развития промышленности, связанной с освоением и использованием источников РЗМ, целенаправленная политика на общегосударственном уровне сочетается с поощением местной инициативы и предприимчивости (при освоении, прежде всего, мелких и относительно менее эффективных источников). По всей видимости (насколько можно судить по разрозненным данным и многочисленным материалам), в основе выбора стратегии развития индустрии РЗМ лежали как политические, так и экономические приоритеты. Основная цель - решение проблем диверсификации экономики и подъема ее научно-технического уровня (а никак не стремление к монополизации производства и мировой торговли РЗМ, как это зачастую можно прочитать в различных аналитических материалах и докладах).

В 1986 г. «архитектор» китайских реформ Дэн Сяопин утвердил «Программу 863», разработанную тремя ведущими учеными, занятыми в ядерной программе страны [14]. В этой программе были сформулированы следующие цели:

- создание направления, обеспечивающего стране выход на передовое место в мире;

- формирование условий для прорыва в ведущих современных технологиях, которые отвечают долгосрочным экономическим интересам страны и содействуют решению проблем ее национальной безопасности;

- развитие ключевых научно-технических направлений, для которых требуются РЗМ (био-, космические, информационные, лазерные технологии, автоматизация, энергетика и минеральные ресурсы). 
Данные цели основывались на учете естественных преимуществ, которыми располагала страна в тот период, - значительного ресурсного потенциала (к тому же недостаточно используемого), наличия неисчерпаемых ресурсов рабочей силы (правда, они весьма неравномерно распределены по территории: Внутренняя Монголия - основной район сосредоточения ресурсов многих твердых полезных ископаемых, не отличается значительным избытком рабочей силы), а также относительной дешевизны добычи и первичного обогащения рассредоточенных полезных ископаемых.

Власти КНР при реализации потенциальных возможностей, вытекающих из наличия колоссальных ресурсов редких земель, следовали прагматичному подходу и «пошаговому» движению в избранном общем направлении.

На первом этапе - рост добычи РЗМ с целью увеличения занятости и формирования основ новой перспективной промышленной деятельности. Главные усилия при этом были сосредоточены на экспорте низкообогащенного сырья.

На втором этапе - расширение использования РЗМ в экономике страны; преимущественный акцент на переработку и получение чистых металлов. Одним из важнейших инструментов стала таможенная политика, связанная с регулированием через квоты экспорта и поставок продуктов переработки на внешний рынок. В ряде случаев от квотирования поставок на экспорт полупродуктов и чистых материалов страна постепенно перешла к существенному ограничению (вплоть до запрета) поставок РЗМ на экспорт. Следствием такой политики стал значительный рост цен на РЗМ на внешних рынках. В 2007 г. Китай ввел систему квотирования поставок РЗМ на экспорт. Например, он прекратил поставку РЗМ ведущему американскому производителю катализаторов - компании WR Grace, и вынудил ее спустя несколько лет открыть производство в Китае.

На современном этапе - вывод промышленности по получению, обогащению и применению РЗМ из «тепличных условий» путем отмены квот и экспортных ограничений [15]. Если ранее Китай игнорировал многие требования ВТО и пренебрегал экологическими нормами, то примерно с 2014 г. он стал соблюдать эти условия и в настоящее время акцентирует внимание 
на повышении конкурентоспособности промышленности по получению РЗМ в ситуации устойчиво низких цен на внешних рынках.

«В начале 2014 г. Госсовет КНР утвердил план создания шести крупных китайских объединений редкоземельных элементов, составленный под руководством Министерства промышленности и информатизации КНР. Этот план призван решить существующие в отечественной редкоземельной индустрии проблемы, связанные с низкой концентрацией производств, невысокой отраслевой конкурентоспособностью и отсутствием возможности (!!!) влиять на мировые цены на редкоземельные элементы» [16]. Так, в июне 2016 г. «...Китайская южная корпорация редкоземельных элементов прошла экспертные слушания... Корпорация находится в городе Ганьчжоу провинции Цзянси (Восточный Китай) и насчитывает 24 дочерние компании. Ее уставный капитал составляет 1 млрд юаней (1 долл. США - 6,63 юаня). Деятельность корпорации охватывает разведку, добычу, отделение и переработку редкоземельных ресурсов... Создание крупных объединений редкоземельной индустрии в Китае будет способствовать трансформации и модернизации этой отрасли в стране, повышению влияния Китая на международных рынках... и превращению Китая в могущественное государство с развитой редкоземельной индустрией» [16].

Результаты показывают, что курс на повышение конкурентоспособности в новых ценовых условиях выбран правильно: «Обороты торговли на Baotou Rare Earth Products Exchange (Китай) в январе-июле 2015 г. резко выросли из-за снижения цен на редкоземельные металлы (РЗМ) и роста спроса. По словам Гу Мина (Gu Ming), генерального директора Baotou Rare Earth Products Exchange, продажи РЗМ достигли 116,4 тыс. т, подскочив на $277 \%$ к уровню аналогичного периода 2014 г. Сумма сделок составила 15,755 млрд юаней (2,57 млрд долл.)... Падение цен на РЗМ привело к активизации спроса на рынке» [17].

В основе подъема промышленности по производству РЗМ в Китае - гибкое сочетание целевых установок на общегосударственном уровне с развитием инициативы и предприимчивости на местах. В частности, важнейшая особенность этой отрасли - отсутствие монополизации. Добычей РЗМ изначально занимались множество мелких фирм, что делало практически 
невозможными их скоординированные действия. Именно такая организационная структура промышленности позволила ей быть очень гибкой и нацеленной на быстрый рост. По мере увеличения спроса в мире на дешевые РЗМ, поставляемые из Китая, все производители стали наращивать их выпуск стремительными темпами.

Издержки производства редкоземельных металлов в КНР были значительно ниже, чем в США и других странах мира, что было также связано с менее жесткими экологическими требованиями законодательства и относительно дешевой рабочей силой [18].

Китай добывает РЗМ не столько исходя из политических целей, сколько (и даже прежде всего) для решения экономических проблем. Рост потребления РЗМ в Китае обусловлен целым рядом обстоятельств - стремлением наращивать производство высокотехнологичной продукции с приемлемыми (низкими) издержками, ростом уровня жизни в стране и увеличением спроса на современные приборы и изделия. Доля внутреннего потребления РЗМ на протяжении последних 10-15 лет стремительно выросла и приближается к 70\%; все меньше их остается для вывоза в другие страны.

Правительство Китая приняло решение в 1970-е «сыграть в долгую игру» - продавать большие объемы РЗМ по таким низким ценам, что мир оказался привязанным к этому дешевому источнику, и многие мощности были закрыты. В этой ситуации рудники Китая остались почти единственным источником получения РЗМ. Китай занял место, которое закрепилось за ним теперь на многие десятилетия вперед - поставщика доступных P3M.

По объемам производства РЗМ Китай впервые стал мировым лидером в 1987 г. и устойчиво превосходил США, начиная с 1992 г. Причины - значительно меньшие издержки, как на стадии добычи, так и переработки, а также поддержка в продвижении данной продукции на внешний рынок со стороны государства.

Страны-конкуренты - США, Австралия, Канада. После того как шок от снижения цен на РЗМ в 2012 г. (2-4-кратное падение на многие их виды) закончился, выяснилось, что в мире к 2015 г. осталось не так много инвестиционно-привлекательных 
компаний в этой сфере. Добыча в основном ведется в Китае, однако эти компании невелики и малоинтересны для инвесторов. За пределами Китая к числу крупнейших в этой отрасли относятся фирмы Австралии - Iluka и Lynas. В США добычей РЗМ занимается только одна компания - Molycorp, и еe рыночная капитализация обрушилась с 6 млрд долл. в 2011 г. до... менее 100 млн долл. в июне 2015 г. Вследствие того, что фирма не приносит прибыли из-за низких цен на продукцию и высоких издержек, в июне 2015 г. она была объявлена банкротом. Единственное ее прибыльное подразделение - сбытовая компании Neo, ориентированная на работу с потребителями РЗМ-продукции.

Во многом схожее положение и у австралийской Lynas, в свое время столь же инвестиционно-привлекательной, как и Molycorp. Хорошие позиции сохраняет компания Iluka, и то только потому, что у нее есть ряд рудников с низкими издержками и выгодным географическим расположением.

Совокупная оценка мощности конкурентов Китая - компаний Molycorp (США) и Lynas (Австралия), которые первыми вышли на рынок после роста цен, составляет 40000 т в год. Увеличение объемов выпуска смогло бы ограничить рыночную власть Китая и превратить рынок в олигополистический с наличием доминирующего производителя. Однако на сегодняшний день этому мешают экономические и экологические ограничения. Тем не менее активный интерес, который проявляют развитые страны мира к рынку РЗМ и диверсификации поставок, способствует росту конкуренции. Но реализации новых проектов и, соответственно, повышению уровня конкуренции на рынке редкоземельных металлов, снижающих риски поставок, могут угрожать следующие факторы.

Высокие затраты на освоение новых месторождений. Месторождения РЗМ сильно различаются по составу руд и базовым минералам, из которых извлекают элементы. Это может потребовать разработки уникальной технологии, пригодной только для конкретного месторождения, а наличие радиоактивных материалов повышает затраты на получение РЗМ.

Низкие цены на редкоземельные металлы, ставшие следствием как внутренней экономической политики Китая (отчасти связанной с отсрочкой выполнения требований ВТО), так и роста производства в других странах мира. 
- Экологические требования в развитых странах зачастую не позволяют им открывать редкоземельное производство на своей территории, поэтому производственные мощности перемещаются в менее развитые страны (например, австралийская Lynas разместила заводы в Малайзии).

- Нехватка кадров.

Значительные риски открытия новых производств РЗМ могут быть снижены посредством государственного участия: правительства Японии, США и Австралии инвестируют до 70\% затрат на реализацию данных проектов [19. Р.181].

Высокое содержание дефицитных тяжелых редкоземельных металлов имеют месторождения Kvanefjeld (Гренландия, компания Greenland Mineral and Energy), Hastings (Австралия, Hastings Rare Metals), Norra Kar (Швеция, Tasman Metals) [20. P.13]. На 2016 г. объявлен запуск австралийского месторождения Hastings, в то время как остальные пока находятся в стадии предварительной оценки. Hastings - сравнительно некрупное месторождение; его оцененные запасы составляют 36 млн т, однако своевременный выход на рынок даст ему конкурентные преимущества.

Основной вывод вполне очевиден - традиционный взгляд на данные активы не всегда приводит к успеху. При этом долгосрочным трендом, определяющим доходность данной отрасли, являются чисто экономические факторы - соотношение спроса и предложения.

Экономические факторы действуют даже и в случае так называемых критических минеральных ресурсов. Так, например, законодатели США в последние годы занимаются проблемами обеспечения страны критическими минеральными ресурсами. В США (как и в Китае и России) имеется значительный накопленный резерв РЗМ для нужд национальной безопасности, однако он сформирован за счет закупок в Китае, хотя Совет по стратегическим минеральным ресурсам настоятельно рекомендует отойти от закупки стратегических РЗМ в Китае и создать в США их собственное производство.

В случае критических минеральных ресурсов (к которым относится часть РЗМ) может быть применен традиционный подход прямого и непосредственного балансирования [21]. В США, например, создан Институт критических ресурсов в структуре 
Эймской лаборатории Министерства энергетики, который является основным координатором работ по данной проблеме. В 2014 г. институт основное внимание сконцентировал на решении проблемы обеспеченности по пяти РЗМ (иттрий, неодим, европий, тербий и диспрозий), а также по литию, который широко применяется в современной альтернативной энергетике, и теллуру. Основные усилия при этом были сфокусированы на диверсификации предложения, создании заменителей, развитии технологий вторичной переработки и повторного использования, а также междисциплинарных исследованиях. Над данными проблемами работали четыре национальные лаборатории Министерства энергетики, шесть компаний и семь университетов.

Политика различных стран в области обеспечения экономики критическими минеральными ресурсами отличается значительным своеобразием [22]. Особенности определяются тем, в каком месте цепочки предложения они находятся. Так, Япония сосредоточилась на поиске заменителей, Китай - на переработке и создании новых материалов, Австралия - на устойчивом развитии горной промышленности, Канада - на поисках и разведке. Южная Корея предполагает инвестировать более 300 млн долл. в течение 10 лет в технологии в области выделения, обогащения, переработки, вторичного использования и создания заменителей.

Страны-потребители - ЕС. Страны ЕС в значительной степени зависят от поставок многих видов минерально-сырьевых ресурсов (не только РЗМ). Место стран ЕС в конце технологических цепочек определяет и особенность подходов к решению проблем обеспечения экономики минерально-сырьевыми ресурсами. В числе важнейших - открытость и акцент на управление знаниями в рамках ЕС. Евросоюз определил свою политику (Raw Materials Initiative - RMI) в сфере улучшения обеспечения экономики минеральными ресурсами в русле трех основных направлений [23-24]: 1) обеспечение доступа к источникам ресурсов в третьих странах на основе принципов открытости и конкурентности; 2) формирование устойчивого предложения минеральных ресурсов из европейских источников и 3) повышение эффективности и развитие вторичного использования.

Важнейшая особенность данной политики - формирование ее на основе более общих принципов и подходов к межгосудар- 
ственным отношениям в современном мире (качество управления, соблюдение прав человека, нацеленность на разрешение конфликтных ситуаций, прозрачность шагов и действий, а также создание добавленной стоимости в развивающихся странах поставщиках минеральных ресурсов).

Отмеченные общие принципы лежат и в основе управления предложением и спросом на минерально-сырьевые ресурсы (в том числе РЗМ) в рамках соответствующих национальных ресурсных стратегий, которое предполагает привлечение к этому процессу и взаимодействие многочисленных общественных институтов с целью поиска современных представлений о том, как лучше ответить на вызовы, стоящие перед той или иной страной. Одно из ключевых условий - участие стейкхолдеров (выгодополучателей) на всех этапах минерально-сырьевой политики (от определения ее целей до реализации, а затем оценки и последующей корректировки).

В принципе возможны несколько подходов к формированию сотрудничества в процессе разработки ресурсных стратегий, различающихся степенью вовлеченности в него государственных структур (как правило, министерств) и негосударственных (бизнеса, общественных организаций, академических и частных научных сообществ, а также институтов гражданского общества).

Важнейший вопрос при создании и использовании новых технологий - обобщение и распространение знаний [25]. Основной акцент делается на создание интегрированной системы управления знаниями, которая позволяла бы легко получать разнообразные сведения как об источниках РЗМ, так и о направлениях их эффективного использования. Такой подход позволяет обеспечить пользователей всей доступной информацией из первичных источников о новых технологиях получения и использования минерально-сырьевых ресурсов.

\section{Достижение баланса при его отсутствии?}

Ключевая проблема при формировании той или иной системы мер и шагов при освоении новых источников РЗМ - балансировка спроса и предложения с учетом различных направлений их использования [26]. Следует не только обеспечить необходимое предложение всех РЗМ, применяемых в современных технологиях (особенно критических РЗМ), но и предотвращать 
шоковые ситуации. В мире нет единого универсального решения для достижения баланса между внутренним спросом и необходимым предложением - как правило, приближение к ситуации равновесия происходит путем комбинации разных подходов и направлений.

Достижение баланса между спросом, складывающимся на рынках, и природным изобилием РЗМ в недрах является серьезнейшей проблемой развития этой отрасли промышленности. В идеальном случае ее решение означает, что по тем элементам, которые находятся в изобилии (легкие РЗМ), будут найдены новые сферы их применения, а по дефицитным (тяжелые РЗМ) определены или их заменители, или другие источники покрытия дефицита. Среди основных подходов к достижению баланса между спросом и предложением, как правило, выделяют диверсификацию источников получения РЗМ, усиление внимания к вторичному применению, активный поиск заменителей, уменьшение использования или создание новых высокоэффективных сфер применения для РЗМ, находящихся в избытке.

В целом на ситуацию с использованием РЗМ влияют низкие издержки на добычу и извлечение, благодаря которым в середине XX века лидерами по их получению стали США, Индия и Бразилия. В 1990-е на рынок вышло значительное число фирм Китая, что в конечном счете привело к росту мирового рынка и неизбежному рекордному снижению цен на РЗМ. Та же причина, по которой США стали заниматься РЗМ-бизнесом - быстрое изменение цен - привела в дальнейшем эту страну почти к полному уходу из данной отрасли.

России необходимо высокоэффективное производство собственных РЗМ, сбалансированное и тесно связанное с расширением внутреннего спроса, без которого нет и не может быть современной и динамичной отрасли применения РЗМ и, соответственно, целого комплекса современных высокотехнологичных производств. Каждая страна проходит свой путь и находит адекватные времени и возможностям ответы. Ответ России в явном виде пока трудно идентифицировать.

\section{Литература}

1. IUPAC Recommendations - 1985 // International Union of Pure and Applied Chemistry. URL://http://iupac.org/recommendation/ 
2. Крюков В.А., Толстов А. В., Самсомов Н. Ю. Стратегическое значение редкоземельных металлов в мире и в России// ЭКО. - 2012. № 11. - С. 5-16.

3. Накамура С. Паника на рынке редких металлов. - Владивосток: Дальнаука, 2009.

4. Темнов А. В., Азарнова Л. А. Роль редких металлов в ресурсном обеспечении стратегическими и критическими видами минерального сырья ведущих зарубежных стран //Минеральные ресурсы: экономика и управление. - 2016. - № 1-2. - С.100-106.

5. Балашова А., Джумайло А. А. Кто и зачем пытается возрождать отрасль РЗМ в России? // Коммерсанть. - 2013. - № 216. - 25 нояб. URL:// http://www.metallopt.ru/test/526042/

6. Государственная программа РФ «Развитие промышленности и повышение ее конкурентоспособности на период до 2020 года» № 1535-p. URL:// http://www.minpromtorg.gov.ru/

7. Паспорт подпрограммы 15 «Развитие промышленности редких и редкоземельных металлов» государственной программы Российской Федерации "Развитие промышленности и повышение ее конкурентоспособности": Постановление правительства РФ от 15.04.2014 г. № 328 // Официальный интернет-портал правовой информации. URL://http://pravo.gov.ru/proxy/ips/?docbody $=\&$ nd $=102352828 \&$ rdk $=\&$ backlink $=1$

8. Быховский Л.3, Темнов А. В., Тигунов Л. П. Об определении понятия «редкие элементы» («редкие металлы»): исторический и терминологический аспекты // Минеральные ресурсы: экономика и управление. - 2015. - № 3. - С.32-38.

9. В ВИАМе обсудили реализацию подпрограммы «Развитие промышленности редких и редкоземельных металлов». - 2016. 15 июн. URL://http://rareearth.ru/ru/news/20160615/02232.html

10. Жамбалнимбуев Б.-Ж. Отчет «О результатах контрольного мероприятия “Проверка расходования средств федерального бюджета и эффективности управления государственным фондом недр редких и редкоземельных металлов в 2011-2014 годах и истекшем периоде 2015 года"». Бюллетень Счетной палаты. - 2016. - № 3. URL://http:// audit.gov.ru/activities/bulleten/872/26265/

11. Итоговый доклад «О результатах и основных направлениях деятельности Роснедр за 2015 год и задачах на 2016 год» // Федеральное агентство по недропользованию. URL:// http://www.rosnedra.gov.ru/ article/8472.html

12. Петров И. М. Российский рынок редких металлов: пути развития // Минеральные ресурсы: экономика и управление. - 2015. - № 1. C.78-81.

13. ОАО «Соликамский магниевый завод»//Годовой отчет за 2015 г. URL://http://смз.pф/index/godovye_otchety/0-11

14. Manceheri N., Sundaresan L., Chandrashekar S. Dominating the World. China and the Rare Earth Industry//International Strategy \& Security Programme (ISSSP), National Institute of Advanced Studies. - Bangalore, April 2013. - $61 \mathrm{p}$. 
15. Китай отменил экспортные квоты на редкоземельные металлы и другую продукцию. URL://http://russian.china.org.cn - 07-01-2015 16. В Китае ускоряется трансформация редкоземельной индустрии. URL://http://russian.china.org.cn - 30-06-2016

17. В Китае активизировалась биржевая торговля РЗМ. - 2015. 17 авг. URL:// http://www.allmetals.ru/index.php?id=40225

18. He Y. Reregulation of China's Rare Earth Production and Export // International Journal of Emerging Markets. - 2014. - Vol. 9. - Iss. 2. P. 236-256.

19. Dadwal S. R. The Sino-Japanese Rare Earths Row: Will China's Loss be India's Gain? // Strategic Analysis. - 2011. - № 35. - Vol. 2.

20. Rare Earths Market Prices, News and Analysis // Argus Rare Earths. 2014. - Iss. 1.

21. Gscheider $K$. The Rare Earth Crisis and the Critical Materials Institute's (CMI'S) Answer // ERES2014:1st European Rare Earth Resources Conference/Milos/04-09/09/2014. URL://http://www.eurare.eu/docs/eres2014/ firstSession/karlGschneidner.pdf

22. Nicoletopoulos V. European Policies on Critical Materials, Including REE// ERES2014:1st European Rare Earth Resources Conference/MiIos/04-09/09/2014. URL://http://www.eurare.eu/docs/eres2014/fourthSession/VasiliNicoletopoulos.pdf

23. European Commission, Tackling the Challenges in Commodity Markets and on Raw Materials//European Commission, Brussels, COM (2011) 25 final, 2011.

24. Endl A., Berger G. A Comparative Analysis of National Policy Approaches - With Focus on Rare Earth Elements in Europe// ERES2014:1st European Rare Earth Resources Conference/Milos/04-09/09/2014. URL:// http://www.eurare.eu/docs/eres2014/fourthSession/AndreasEndl.pdf

25. Cassard D., Tertre F., Bertrand G., Schjoth F., Tulstrup J., Heijboer T., Vuollo J. EuRare IKMS: An Integrated Knowledge Management System for Rare Earth Element Resources in Europe // ERES2014:1st European Rare Earth Resources Conference/Milos/04-09/09/2014. URL://http://www. eurare.eu/docs/eres2014/fifthSession/GuillaumeBertrand.pdf

26. Binnemans $K$. Economics of rare Earth: The Balance Problem// ERES2014:1st European Rare Earth Resources Conference/Milos/04-09/09/2014. URL://http://www.eurare.eu/docs/eres2014/firstSession/koenBinnemans.pdf 